\title{
Response of rainbow trout (Oncorhynchus mykiss) in skin and fin tissue during infection with a variant of Gyrodactylus salaris (Monogenea: Gyrodactylidae)
}

\author{
Thomas R. Jørgensen, Martin K. Raida, Per W. Kania and Kurt Buchmann
}

Department of Veterinary Disease Biology, Laboratory of Fish Diseases, Faculty of Life Sciences, University of Copenhagen, Stigbøjlen 7, 1870 Frederiksberg C., Denmark

\begin{abstract}
Response mechanisms of rainbow trout Oncorhynchus mykiss (Walbaum), experimentally infected with a Danish strain of Gyrodactylus salaris Malmberg, 1957 were investigated using molecular tools (qPCR) and immunohistochemistry. Expression of ten immune-relevant genes and reactivity with five different antibodies in the epidermis of skin and fin tissue were analysed in susceptible but responding rainbow trout. Rainbow trout were susceptible with regard to the parasite strain which initially colonised fins but relocated to the body region as infection progressed. The ten investigated genes encoding the cytokines IL- $1 \beta$, TNF- $\alpha$, IFN- $\gamma$, IL-10 and markers for adaptive immune activity, such as CD-4, CD-8, TCR- $\alpha$, IgM, IgT and MHC II, were not found significantly regulated during the course of infection although IFN- $\gamma$ showed a slight up-regulation. Immunohistochemical analyses showed positive reactivity with antibodies against CD3, B-lymphocytes, neutrophilic granulocytes and collectin but not with mAb against IgM. No staining differences between infected and non-infected skin and fin tissue were detected.
\end{abstract}

Key words: immune response, real-time PCR, immunohistochemistry, rainbow trout, Gyrodactylus salaris

The monogenean parasite Gyrodactylus salaris Malmberg, 1957 has caused serious stock decreases of wild Atlantic salmon Salmo salar L. in more than 46 Norwegian rivers (Johnsen 1978, Johnsen and Jensen 1986, Heggberget et al. 1993, Appleby and Mo 1997). Controlled laboratory experiments have shown that East Atlantic salmon strains such as Norwegian, Scottish, Irish and Danish salmon are highly susceptible towards G. salaris, whereas salmon homing in Baltic rivers have an ability to control the infection (Bakke and MacKenzie 1993, Bakke et al. 2002, Dalgaard et al. 2003, Lindenstrøm et al. 2006, Heinecke et al. 2007, Kania et al. 2007). The G. salaris form found in Danish rainbow trout Oncorhynchus mykiss (Walbaum) farms is non-pathogenic to both East Atlantic and Baltic salmon strains (Jørgensen et al. 2007). This form does not have the potential to spread to wild Danish salmon (Jørgensen et al. 2008). In contrast, spreading of the pathogenic parasite form to uninfected countries such as Denmark and the UK is of great concern due to the presence of highly susceptible salmon in these countries. The Danish rainbow trout form of $G$. salaris has recently been isolated by Jørgensen et al. (2007) and the susceptibility of East Atlantic salmon, Baltic salmon and rainbow trout to infection with the parasite was tested. The study showed that the two salmon strains were resistant and able to control the infection caused by this particular strain of G. salaris. Rainbow trout, in contrast, sustained consider- ably larger parasite populations compared to East Atlantic and Baltic salmon (Jørgensen et al. 2007). Previously another G. salaris-like strain has been isolated and characterised. However, this strain was both morphologically and genetically different from the strain investigated in the present study (Lindenstrøm et al. 2003) A number of studies during the latest decade have elucidated the possible immune mechanisms behind the ability of salmonids to control Gyrodactylus infection (Harris et al. 1998, Buchmann and Bresciani 1999, Buchmann and Lindenstrøm 2002, Lindenstrøm et al. 2006, Matejusová et al. 2006, Collins et al. 2007, Kania et al. 2007). These studies have indicated that a series of immune-relevant factors such as complement activity, leucocyte activity, and increased production of pro-inflammatory cytokines in susceptible salmon are involved in the host response. The present study elucidates the immune response in rainbow trout against the non-pathogenic variant of $G$. salaris.

\section{MATERIALS AND METHODS}

Fish. Naive rainbow trout Oncorhynchus mykiss (Walbaum) hatched and reared under pathogen-free conditions (Danish Centre for Wild Salmon, Randers, Jutland), were, at a size of approx. $15 \mathrm{~g}$, transported to the experimental facilities at the University. Water used in the experiments was a mixture of $50 \%$ deionised water and 50\% municipal water (Frederiksberg, Denmark). Fish were kept in a temperature-controlled room at

Address for correspondence: K. Buchmann, Department of Veterinary Disease Biology, Laboratory of Fish Diseases, Faculty of Life Sciences, University of Copenhagen, Stigbøjlen 7, 1870 Frederiksberg C., Denmark. Phone:+45-35332700; Fax:+45-35332711; E-mail: kub@life.ku.dk 
$12-13^{\circ} \mathrm{C}$. A total of 3 tanks were used (two infected replicates and one control), each with a total volume of 1501 aerated water. Using internal filters (Eheim, Germany), the ammonium and nitrite concentrations were kept at below $0.1 \mathrm{mgl}^{-1}$ and zero, respectively (Merck Aquacant, Merck, Germany). Half of the water was changed twice a week. At the start of the experiment fish had a mean body weight of $24.7 \mathrm{~g}(\mathrm{SD}=2.98)$ and a mean length of $142.4 \mathrm{~mm}$ (SD 9.43).

Challenge infection and monitoring of parasites. Rainbow trout (20 in each tank) were acclimated for 3 weeks prior to infection, which was induced by placing one infected (euthanised) rainbow trout carrying 50 parasites in each tank. The parasite used was Gyrodactylus salaris Malmberg, 1957 (Danish strain) (Jørgensen et al. 2007). The control tank was sham-infected by adding an uninfected rainbow trout. After $24 \mathrm{~h}$ the donor fish were removed and the parasite abundance (Bush et al. 1997) and the microhabitat distribution (Buchmann and Uldal 1997) on the recipient fish were recorded at day 1, 22 and 33. Tissue sampling for gene expression analysis and immunohistochemistry was performed on the same day but from non-manipulated fish.

Tissue sampling for real-time qPCR. Five fish (one fish at a time) from each group were rapidly netted and killed in an overdose of MS222 (Sigma-Aldrich, Denmark) $500 \mathrm{mgl}^{-1}$. The left pelvic fin was immediately removed and placed in RNAlater (Sigma-Aldrich, Denmark). Furthermore, a skin sample $(1.5 \times 4 \mathrm{~cm})$ was removed from the left side of each fish (below the dorsal fin) and placed in RNA-later. Samples in RNA-later were stored at $24 \mathrm{~h}$ at $5^{\circ} \mathrm{C}$ and subsequently stored at $-20^{\circ} \mathrm{C}$ until RNA isolation.

Isolation of RNA and synthesis of cDNA. Fins and skin samples were sonicated on ice (Sonicator Ultrasonic Liquid Proseccor XL2020, Heat Systems, USA). Total RNA was isolated using a commercial kit (RTN350, Sigma-Aldrich, Denmark) according to the manufacturer's instructions. The quality and quantity of the isolated RNA was measured by spectrophotometry (OD260/280) (BIORAD SmartSpec ${ }^{\mathrm{TM}}$, USA). Following adjustment of mRNA concentration and DNAse treatment (DNase I, Sigma-Aldrich, Denmark) of all samples, cDNA synthesis was performed using random hexamer primed reverse transcription following the manufacturer's instructions (Applied Biosystems, Denmark). Reaction volumes were $20 \mu \mathrm{l}$. Following cDNA synthesis the samples were diluted 1:10 in RNAsefree water and stored at $-20^{\circ} \mathrm{C}$.

Real-time PCR. PCR was performed on a real-time PCR machine (MX3000PTM, Stratagene, USA). HPLC-purified primers and TaqMan ${ }^{\circledR}$ probes conjugated to HEX or CY-5 as well as BHQs were used. Primers and probes are presented in Table 1. A SYBR Green assay was used to conduct melting point analysis of primers as described by Raida and Buchmann (2008). Ten fold serial dilutions of cDNA were made to ensure primer and probe efficiency within the working range. PCR cycling for all samples were $94^{\circ} \mathrm{C}$ for 2 min followed by 40 cycles of $94^{\circ} \mathrm{C}$ for $30 \mathrm{~s}$ and $60^{\circ} \mathrm{C}$ for $1 \mathrm{~min}$. PCR reactions $(12.5 \mu \mathrm{l})$ containing the following components were conducted: $6.25 \mu \mathrm{l}$ JumpStartTM Taq ReadyMixTM, 1.5-5 mM $\mathrm{MgCl}_{2}, 0.5 \mu 1$ probe $(0.5 \mu \mathrm{M}), 0.5 \mu \mathrm{l}$ forward and reverse primer $(10 \mu \mathrm{M})$, $2.5 \mu$ template, RNAse-free water to final volume. All reagents were purchased from Sigma-Aldrich, Denmark. Negative controls were conducted by replacing template with RNAse-free water. Elongation factor EF1- $\alpha$ was used as reference gene/endogenous control.

Immunohistochemistry. Immediately after tissue sampling for real-time PCR at day 33, the right pelvic fin and a skin sample $(1.5 \times 4 \mathrm{~cm})$ from the right side of the fish was removed and placed in neutral buffered formalin $(4 \%, \mathrm{pH} 7.2)$ for $24 \mathrm{~h}$ and finally stored in $70 \%$ ethanol until paraffin-embedding according to standard histological methods. De-paraffination was accomplished by heating slides to $70^{\circ} \mathrm{C}$ for 12 min followed by xylene

Table 1. Forward primers (Fwd.), reverse primers (Rev.) and probes used in real-time PCR gene expression analysis of immunerelevant genes. The GenBank accession number (Acc. No.) for each gene is given. PCR efficiency (Eff.) is given.

\begin{tabular}{|c|c|c|c|c|}
\hline Gene & Acc. No. & Primer & Probe & Eff. $(\%)$ \\
\hline EF1- $\alpha$ & AF498320 & $\begin{array}{l}\text { Fwd. ACTCCCCTCTGTCACACACC } \\
\text { Rev. GGCAGACAGGTCCTCCACTA }\end{array}$ & GCTGTGCGTGACATGAGGCA & 100.0 \\
\hline CD4 & AY973028 & $\begin{array}{l}\text { Fwd. CATTAGCCTGGGTGGTCAAT } \\
\text { Rev. CCCTTTCTTTGACAGGGAGA }\end{array}$ & CAGAAGAGAGAGCTGGATGTCTCCG & 98.6 \\
\hline CD8 & AF178054 & $\begin{array}{l}\text { Fwd. ACACCAATGACCACAACCATAGAG } \\
\text { Rev. GGGTCCACCTTTCCCACTTT }\end{array}$ & ACCAGCTCTACAACTGCCAAGTCGTGC & 104.5 \\
\hline IL-6 & DQ866150 & $\begin{array}{l}\text { Fwd. ACTCCCCTCTGTCACACACC } \\
\text { Rev. GGCAGACAGGTCCTCCACTA }\end{array}$ & CCACTGTGCTGATAGGGCTGG & 104.7 \\
\hline IL-1 $\beta$ & AJ223954 & $\begin{array}{l}\text { Fwd. ACATTGCCAACCTCATCATCG } \\
\text { Rev. TTGAGCAGGTCCTTGTCCTTG }\end{array}$ & GCTGTGCGTGACATGAGGCA & 99.7 \\
\hline IL-10 & AB118099 & $\begin{array}{l}\text { Fwd. CGACTTTAAATCTCCCATCGAC } \\
\text { Rev. GCATTGGACGATCTCTTTCTTC }\end{array}$ & CATCGGAAACATCTTCCACGAGCT & 101.7 \\
\hline IFN- $\gamma$ & AY795563 & $\begin{array}{l}\text { Fwd. AAGGGCTGTGATGTGTTTCTG } \\
\text { Rev. TGTACTGAGCGGCATTACTCC }\end{array}$ & TTGATGGGCTGGATGACTTTAGGA & 102.4 \\
\hline TNF- $\alpha$ & AJ277604 & $\begin{array}{l}\text { Fwd. GGGGACAAACTGTGGACTGA } \\
\text { Rev. GAAGTTCTTGCCCTGCTCTG }\end{array}$ & GACCAATCGACTGACCGACGTGGA & 99.9 \\
\hline $\operatorname{IgT}$ & AY870265 & $\begin{array}{l}\text { Fwd. AGCACCAGGGTGAAACCA } \\
\text { Rev. GCGGTGGGTTCAGAGTCA }\end{array}$ & AGCAAGACGACCTCCAAAACAGAAC & 98.5 \\
\hline $\operatorname{IgM}$ & S63348 & $\begin{array}{l}\text { Fwd. CTTGGCTTGTTGACGATGAG } \\
\text { Rev. GGCTAGTGGTGTTGAATTGG }\end{array}$ & TGGAGAGAACGAGCAGTTCAGCA & 98.4 \\
\hline TCR & AF329700 & $\begin{array}{l}\text { Fwd. TCACCAGCAGACTGAGAGTCC } \\
\text { Rev. AAGCTGACAATGCAGGTGAATC }\end{array}$ & CCAATGAATGGCACAAACCAGAGAA & 96.6 \\
\hline SAA & X99385 & $\begin{array}{l}\text { Fwd. GGGAGATGATTCAGGGTTCCA } \\
\text { Rev. TTACGTCCCCAGTGGTTAGC }\end{array}$ & TCGAGGACACGAGGACTCAGCA & 99.9 \\
\hline MHC II & AF115533 & $\begin{array}{l}\text { Fwd. TGCCATGCTGATGTGCAG } \\
\text { Rev. GTCCCTCAGCCAGGTCACT }\end{array}$ & CGCCTATGACTTCTACCCCAAACAAAT & 101.1 \\
\hline
\end{tabular}


submersion and subsequent re-hydration in graded ethanol series $(99 \%, 96 \%$ and $70 \%$ ethanol). Heat-induced epitope retrieval was accomplished by microwave-oven incubation $(2 \times 5 \mathrm{~min})$ in $0.01 \mathrm{M}$ citrate buffer, $\mathrm{pH}$ 6.0. To avoid non-specific binding, slides were blocked for 10 min with 5\% BSA in TBS at RT. Positive control slides were made by sectioning a multi-blocks (rainbow trout spleen, liver, skin, gill, intestine and head kidney in one paraffin section). The organs were collected from rainbow trout 24 h post i.p. injection with $1000 \mu$ l Freund's Complete Adjuvant (Sigma-Aldrich, Denmark) to ensure immunological activity. Positive control tissue was removed, fixed, paraffinembedded and treated as described above. Subsequently, the positive control tissue was stained with the same antibodies as test tissue using the same procedure as described below for each antibody respectively.

Polyclonal rabbit antibody (anti CD3). A commercial kit (EnVision ${ }^{\circledR}+$ System-HRP (AEC), K4008, DakoCytomation, Denmark) was used for blocking endogenous peroxidase activity, labelling with the secondary antibody, and visualisation. In brief, $0.03 \%$ hydrogen peroxide was used to block endogenous peroxidase activity ( $5 \mathrm{~min}$ at RT). Primary antibody, a polyclonal rabbit anti-human T-cell CD3 specific to the cytoplasmic $\varepsilon$-chain of CD3 (A0452, Dako, Denmark) (Bakke-McKellep et al. 2007) was applied for $18 \mathrm{~h}$ at $4{ }^{\circ} \mathrm{C}$ (diluted 1:100) in 5\% BSA in TBS. Each slide was incubated with a secondary peroxidase-labelled goat anti-rabbit antibody for $30 \mathrm{~min}$ at RT. To visualise peroxidase activity, slides were incubated with 3-amino-9-ethylcarbazole $(\mathrm{AEC}+)$ substrate chromogen solution for $20 \mathrm{~min}$ at RT. Tissues were counterstained with haematoxylin for $30 \mathrm{~s}$, washed and incubated with $\mathrm{NaCHO}_{3}$ in $70 \%$ ethanol (pH 10) for 2 min and mounted in Aquamount (362262H, BDH, England). For all antibodies used in this study, negative controls were made by substituting primary antibody with 5\% BSA in TBS.

Monoclonal mouse antibody (anti-trout IgM). Endogenous peroxidase activity was blocked by peroxidase blocking reagent (S2001, Dako, Denmark) for $5 \mathrm{~min}$. Slides were incubated with primary antibody labelled with HRP (monoclonal mouse anti-trout IgM, Aquatic Diagnostics, Stirling, UK) for $1 \mathrm{~h}$ and visualised by DAB (SIGMA FAST ${ }^{\mathrm{TM}}$ D4293-50SET, SigmaAldrich, Denmark). Counter staining, mounting and negative controls were conducted as described for CD3 staining above.

Monoclonal mouse antibody (anti-trout collectin). EnVision ${ }^{\circledR}+$ System-HRP (AEC) (K4004, DakoCytomation, Denmark) was used for blocking endogenous peroxidase activity, labelling with the secondary antibody, and visualisation. Primary antibody, a monoclonal mouse anti-trout collectin, diluted 1:3 in 5\% BSA in TBS (Kania et al. 2005), was applied for $18 \mathrm{~h}$ at $4{ }^{\circ} \mathrm{C}$. Each slide was incubated with a secondary peroxidaselabelled goat anti-mouse antibody for $30 \mathrm{~min}$ at RT. To visualise peroxidase activity, slides were incubated with AEC+ substrate chromogen solution for $20 \mathrm{~min}$ at RT.

Monoclonal mouse antibody (anti-trout neutrophilic granulocyte). EnVision ${ }^{\circledR}+$ System-HRP (AEC) (K4004, DakoCytomation, Denmark) was used. Primary antibody (E3D9) (Pettersen et al. 2005) was diluted 1:1 in 5\% BSA in TBS and applied for $18 \mathrm{~h}$ at $4{ }^{\circ} \mathrm{C}$.

Monoclonal mouse antibody (anti-trout B-lymphocyte). EnVision ${ }^{\circledR}+$ System-HRP (AEC) (K4004, DakoCytomation, Denmark) was used. Primary antibody (G2H3) (Pettersen et al. 2005) was diluted to $2 \mu \mathrm{g} / \mathrm{ml}$ in 5\% BSA in TBS and applied for $18 \mathrm{~h}$ at $4^{\circ} \mathrm{C}$.
Data analysis, real-time PCR. The $2^{-\Delta \Delta C t}$ method was used to analyze PCR results according to Livak and Schmittgen (2001). Briefly, for each sample, the difference between expression of the housekeeper gene and the target gene $(\Delta \mathrm{Ct})$ was calculated as the difference in $\mathrm{C}_{t}$ values between the two genes. The mean $\Delta \mathrm{Ct}$ values of the uninfected control groups were calculated. $\Delta \Delta \mathrm{Ct}$ values were calculated as the difference in $\Delta \mathrm{Ct}$ values between each sample and the mean value of the uninfected control group. The fold change for each gene was calculated as $2^{-\Delta \Delta C t}$. A Mann-Whitney U-test was used to test differential expression between groups, with a probability level of $5 \%$.

\section{RESULTS}

\section{Challenge infection and monitoring of pathogen}

Abundance data from the two replicates were not statistically different. Thus, data from the two replicates were pooled and the abundance was calculated and presented in Fig. 1. At day 1 post challenge the abundance was 5.5. At day 22 and 33 the abundance was 76.4 and 284.3 , respectively. Prevalence was $100 \%$ throughout the experiment. Parasites infected the host via the fins. At day 1 post challenge $84.5 \%$ of all parasites were infecting fin tissue whereas $71 \%$ and $72.8 \%$ of all parasites were infecting skin tissue at day 22 and 33 post-challenge, respectively (Fig. 1). Control fish were confirmed parasitefree throughout the study.

\section{Real-time PCR}

The constitutive expression of the tested genes in control fish (skin and fins) at day 1 is presented as the basic transcript (Ct values) of control fish fins and skin, respectively (Figs. 2 and 3). During the course of infection no genes encoding immune parameters were significantly regulated. However, the IFN- $\gamma$ gene was slightly but non-significantly up-regulated (Mann Whitney U-test, $\mathrm{P}=0.17$ ) (Table 2).

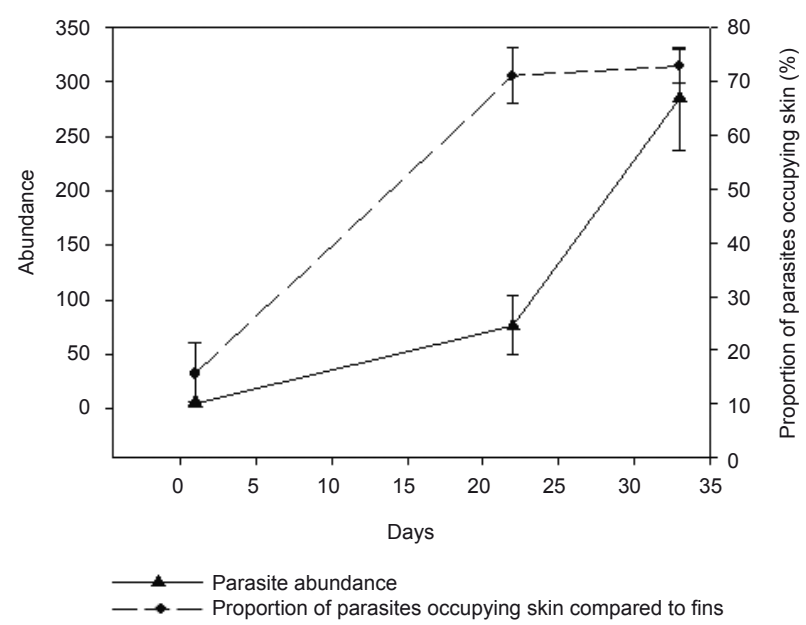

Fig. 1. Rainbow trout (Oncorhynchus mykiss) infected with the Danish variant of Gyrodactylus salaris. Course of experimental infection during 33 days showing abundance and the proportion of the parasite population located on the skin. 


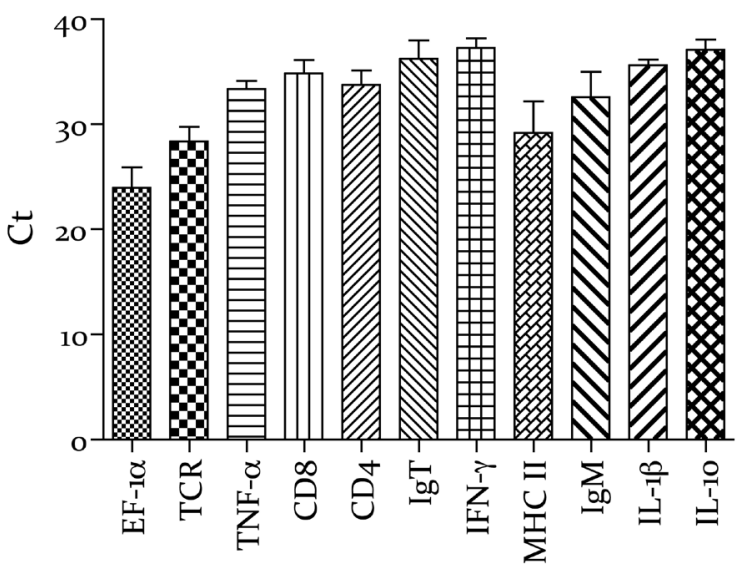

Fig. 2. QPCR conducted for ten immune-relevant genes in skin of rainbow trout (Oncorhynchus mykiss). The diagram shows the $\mathrm{Ct}$ values for the uninfected control fish at day 1 describing the constitutive expression of genes in non-stimulated fish. Mean and SD of five fish.

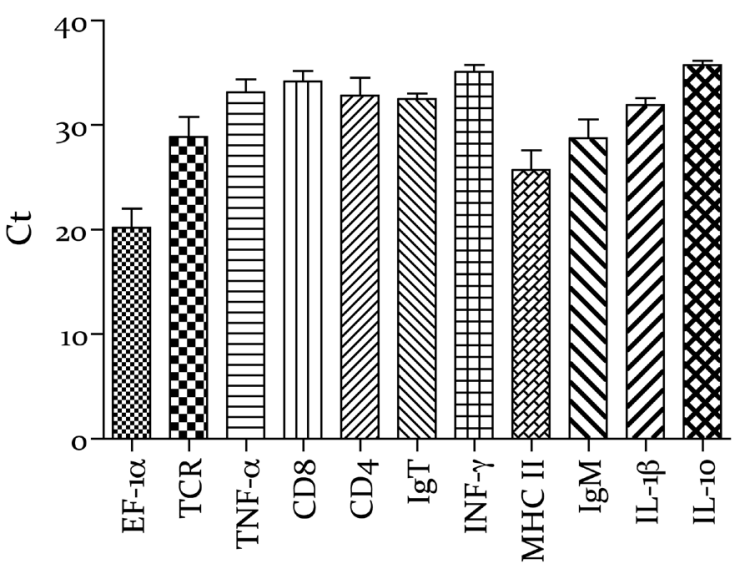

Fig. 3. QPCR conducted for ten immune-relevant genes in fins of rainbow trout (Oncorhynchus mykiss). The diagram shows the $\mathrm{Ct}$ values for the uninfected control fish at day 1 describing the constitutive expression of genes in non-stimulated fish. Mean and SD of five fish.

\section{Immunohistochemistry}

All results are from fin and skin tissue sampled at day 33 post infection (p.i.). Results are visualised in Fig. 4. Non-stained negative control sections are not shown.

\section{Polyclonal rabbit antibody (anti-human T-cell CD3)}

Cells in skin and fin tissue from rainbow trout infected with G. salaris showed weak reactivity with a polyclonal antibody raised against the human T-cell $\mathrm{CD} 3 \varepsilon$ chain. Reactivity was seen in both infected and non-infected control tissue (in both skin and fins). In the skin, stained cells were predominantly observed among the epithelial cells. In fin tissue, stained cells were also seen in the epidermis; however, the density of reactive cells was higher in skin compared to fin tissue (Fig. 4). No staining difference be-
Table 2. Oncorhynchus mykiss infected with the Danish strain of Gyrodactylus salaris. Expression of ten immune-relevant genes in the skin and fins of infected trout compared to uninfected trout (time point controls). Values were tested by Mann-Whitney U-test and no significant differences were found. Therefore fold up- or down-regulations are not shown.

\begin{tabular}{|c|c|c|c|c|c|}
\hline \multirow[t]{2}{*}{ Gene } & \multirow[t]{2}{*}{ Day } & \multicolumn{2}{|c|}{ Fins } & \multicolumn{2}{|c|}{ Skin } \\
\hline & & $\Delta \Delta \mathrm{Ct}$ & SEM & $\Delta \Delta \mathrm{Ct}$ & SEM \\
\hline \multirow{3}{*}{ MHC II } & 1 & -0.36 & 0.15 & -5.33 & 0.36 \\
\hline & 21 & 0.15 & 0.27 & -1.46 & 0.32 \\
\hline & 31 & 0.10 & 0.27 & 1.35 & 0.23 \\
\hline \multirow{3}{*}{ IL-1 $\beta$} & 1 & 0.66 & 0.36 & -4.89 & 1.48 \\
\hline & 21 & -1.83 & 0.36 & -0.60 & 1.46 \\
\hline & 31 & -0.16 & 0.71 & -3.54 & 1.46 \\
\hline \multirow{3}{*}{ IL-10 } & 1 & 0.09 & 0.31 & -0.23 & 1.54 \\
\hline & 21 & -1.62 & 0.93 & 1.79 & 1.64 \\
\hline & 31 & -2.48 & 0.72 & -2.85 & 1.80 \\
\hline \multirow{3}{*}{ IFN- $\gamma$} & 1 & -0.45 & 0.15 & -1.02 & 1.34 \\
\hline & 21 & 0.89 & 0.23 & 7.56 & 1.84 \\
\hline & 31 & -1.40 & 0.38 & 8.03 & 1.79 \\
\hline \multirow{3}{*}{ TNF- $\alpha$} & 1 & 0.13 & 0.17 & -6.78 & 0.50 \\
\hline & 21 & 0.50 & 0.21 & 3.02 & 0.69 \\
\hline & 31 & 0.27 & 0.39 & 3.03 & 0.68 \\
\hline \multirow{3}{*}{ IgM } & 1 & -0.27 & 0.27 & -5.15 & 0.29 \\
\hline & 21 & 0.85 & 0.35 & -2.55 & 0.62 \\
\hline & 31 & 0.70 & 0.32 & -7.31 & 0.49 \\
\hline \multirow{3}{*}{$\operatorname{IgT}$} & 1 & 1.53 & 1.95 & -3.08 & 2.28 \\
\hline & 21 & -3.26 & 3.68 & -6.28 & 2.12 \\
\hline & 31 & -3.88 & 1.94 & -7.18 & 1.59 \\
\hline \multirow{3}{*}{ TCR } & 1 & -0.06 & 0.15 & -7.92 & 0.34 \\
\hline & 21 & -0.04 & 0.23 & -3.20 & 0.53 \\
\hline & 31 & -0.31 & 0.36 & 2.55 & 0.46 \\
\hline \multirow{3}{*}{ CD8 } & 1 & -0.38 & 0.25 & -5.66 & 0.20 \\
\hline & 21 & 0.73 & 0.20 & -7.31 & 1.46 \\
\hline & 31 & 0.70 & 0.44 & -2.04 & 1.28 \\
\hline \multirow{3}{*}{ CD4 } & 1 & 0.44 & 0.23 & -5.56 & 0.42 \\
\hline & 21 & 0.87 & 0.28 & -5.60 & 1.56 \\
\hline & 31 & -0.90 & 0.40 & 2.81 & 0.48 \\
\hline
\end{tabular}

tween infected and non-infected trout was observed, and no cell staining was seen in negative control tissue.

\section{Monoclonal mouse antibody (anti-trout IgM)}

No binding of the primary antibody against IgM was observed in skin and fin tissue of rainbow trout.

\section{Monoclonal mouse antibody (anti-trout collectin)}

The monoclonal mouse antibody against trout collectin showed strong staining of rainbow trout mucous cells scattered in the epidermal layer of both skin and fins, indicating the presence of collectins or other polysaccharide epitopes in rainbow trout mucus. No staining difference between infected and non-infected trout was observed, and no cell staining was seen in negative control tissue. 


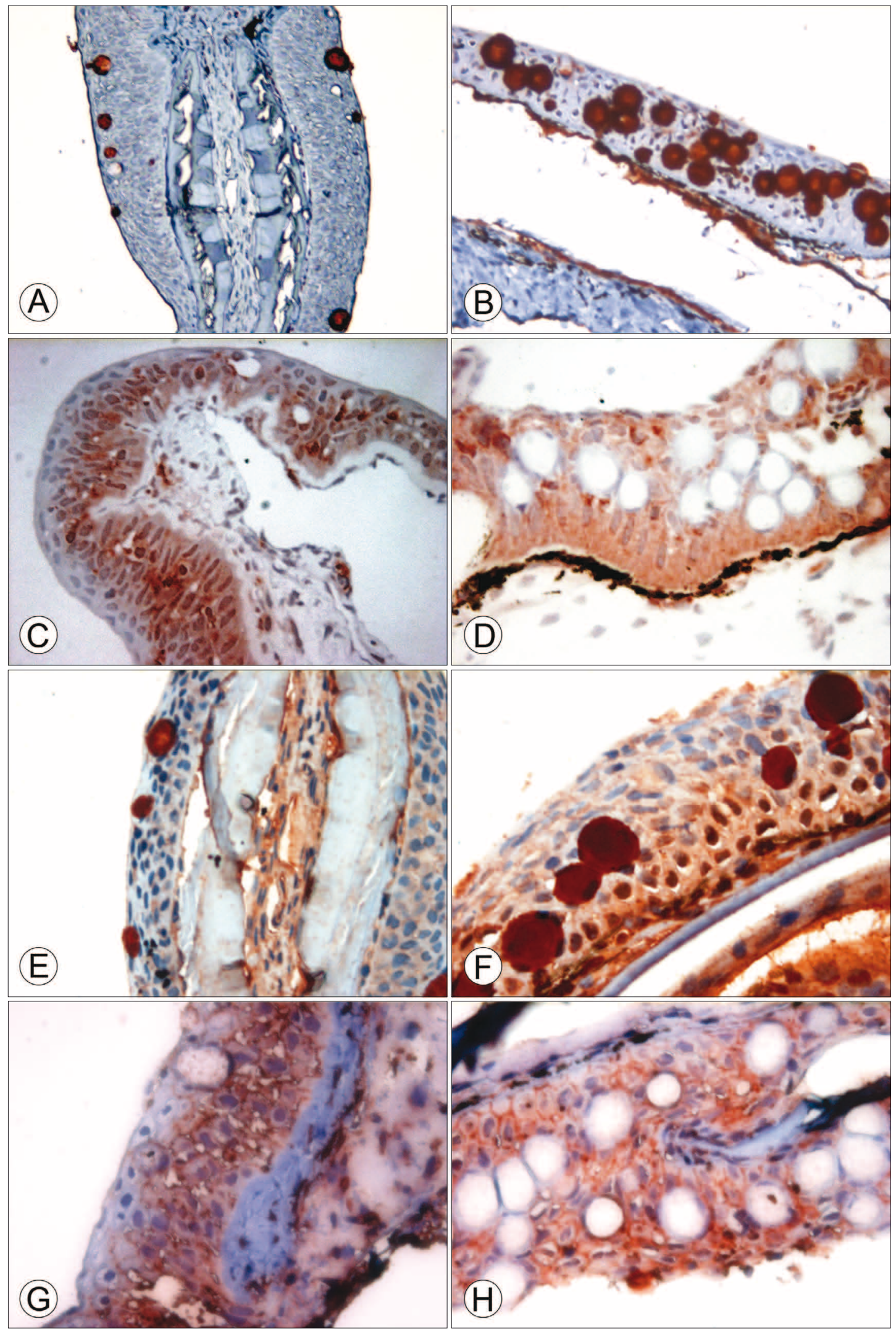

Fig. 4. Immunohistochemical staining of fin and skin tissue from rainbow trout (Oncorhynchus mykiss) 33 days p.i. with the Danish strain of Gyrodactylus salaris. A, B - fin and skin, respectively, incubated with Ab against neutrophilic granulocytes $(\times 180)$; C, D - fin and skin, respectively, incubated with Ab against CD3 $(\times 360) ; \mathbf{E}, \mathbf{F}-$ fin and skin, respectively, incubated with Ab against collectin $(\times 360)$. G, $\mathbf{H}-$ fin and skin, respectively, incubated with Ab against B-lymphocytes $(\times 360)$. 


\section{Monoclonal mouse antibody (anti-trout neutrophilic granulocyte)}

Monoclonal antibody against neutrophilic granulocytes stained mucous cells in the epidermis of skin and fin tissue. In skin, staining of a few cells scattered between the epidermal cells was seen. In addition, staining of cell remnants beneath the basal membrane was observed. No staining difference between infected and non-infected trout was observed, and no cell staining was seen in negative control tissue.

\section{Monoclonal mouse antibody (anti-trout B-lymphocyte)}

Staining against B-lymphocytes showed reactivity with cells scattered between epidermal cells in both skin and fin tissue. In fin tissue reactivity of cells just beneath the basal membrane was also observed. Reactivity in cells of several tissue layers beneath the epidermis was seen in skin. No staining differences in the skin were found between infected and uninfected rainbow trout. No cell staining was seen in negative control tissue.

\section{DISCUSSION}

The parasite burdens recorded at days 22 and 33 p.i. correspond to parasite abundances reported from a previous study where infection of rainbow trout was performed using the same laboratory strain of Gyrodactylus salaris (Jørgensen et al. 2007). Thus, the present results confirm that rainbow trout are susceptible towards infection with the Danish strain of G. salaris. The present challenge infection was only sustained for 33 days and consequently a decline in parasite numbers was not observed. However, the study by Jørgensen et al. (2007) showed that rainbow trout responded and controlled infection with the Danish strain of G. salaris when infection progresses over a longer period (42 days). A clear trend for an initial colonisation of the ventral fins was observed but translocation to the body region was evident at days 22 and 33. This confirms that microhabitat selection of the Danish strain of $G$. salaris is largely opposite to what is observed during infection with G. salaris from Norway where fins are the preferred attachment sites throughout infection (Jensen and Johnsen 1992, Heinecke et al. 2007).

The mechanisms responsible for immune response and susceptibility of salmonids infected with gyrodactylids have not been fully resolved although both cellular and humoral factors have been considered by various authors. Several recent studies have attempted to elucidate the possible mechanisms involved in host response (Buchmann and Lindenstrøm 2002, Lindenstrøm et al. 2003, 2004, 2006, Buchmann et al. 2004, Matejusová et al. 2006, Collins et al. 2007, Kania et al. 2007). The studies mentioned above treated heavily infected host fishes whereas the present study is based on fish with a lower infection level.

Expression of ten immune-relevant genes in fins and skin was investigated in the present study and no genes were significantly regulated. A possible reason is that the parasite load on the skin and fins recorded in the present study is clearly lower compared to other studies. Thus, the Danish strain of G. salaris, used in the present study, proliferated to a moderate level on the skin and not on the fin tissue which was largely uninfected at 33 days p.i. Therefore, a more pronounced immune reaction would be expected in heavily infected fish studied by Dalgaard et al. (2003, 2004) and Lindenstrøm et al. (2006). Thus, it should be mentioned that the present study does not clarify if the lack of immune gene regulation reflects parasite species or parasite intensity. The basic response mechanisms responsible for the population decline of the Danish G. salaris strain on rainbow trout (Jørgensen et al. 2007) is at present unknown but our results indicate that a series of other genes should be investigated in the future. Matejusová et al. (2006) found a significant up-regulation of a gene with sequence similarities to myeloid leukaemia differentiation protein (Mcl-1) in the skin of G. salaris-susceptible salmon. Human Mcl-1 is induced by IL-1, which has been suggested to play a role in host defence against Gyrodactylus infections (Buchmann and Bresciani 1999, Lindenstrøm et al. 2003, 2006). Lindenstrøm et al. (2003) demonstrated an up-regulation of IL-1 $\beta$ in susceptible rainbow trout following infection with Gyrodactylus derjavinoides. Furthermore, a hyperactivation of IL- $1 \beta$ was seen in highly susceptible Scottish salmon infected with G. salaris, indicating that high expression of this particular cytokine promotes elevated parasite intensity by an inappropriate inflammatory response resulting in excess mucus production (Lindenstrøm et al. 2006). A similar role has been suggested for the recently characterised FIP2 gene (Collins et al. 2007). The present work showed no regulation of IL-1 $\beta$ in fin and skin tissue, which probably is a result of the low infection intensities. A semi-quantitative study on rainbow trout infected with $G$. derjavinoides indicated a small upregulation of TNF- $\alpha 1$ in skin 8 days p.i. (Lindenstrøm et al. 2004). Another pro-inflammatory cytokine, IFN- $\gamma$ was slightly but non-significantly upregulated in the present study in skin 33 days p.i. The anti-inflammatory cytokine IL-10 was un-regulated in fins and skin at the sampling points. Among other functions, IL-10 is considered to prevent harmful immune reactions by regulating the inflammatory response. However, the function of this cytokine in fish is still less well characterised and its precise role still needs clarification. At least its role in skin responses against $G$. salaris was not supported in this study.

Markers for antigen presentation and T-cell mediated adaptive immune activity (CD-4, CD-8, TCR- $\alpha$ and MHC II) were all un-regulated in infected rainbow trout, indicating that presentation of Gyrodactylus epitopes and subsequent cellular response by T-cells is absent or under detection level. Our study also showed that adaptive humoral immune responses (IgM and $\operatorname{IgT}$ ) mediated by antibodies were un-regulated during infection. The un-regulated adaptive parameters observed in our study suggest that 
adaptive immunity is of little importance when rainbow trout respond and control infection with the Danish strain of G. salaris. However, this study does not show the adaptive immune reaction during infection with high parasite abundance. Based on our results, further studies should be performed in order to dissect factors in fish skin which elicit a population decline despite the absence of excessive inflammation and activation of immune genes. The immunohistochemical investigations of Gyrodactylus infection in salmonids could aid in elucidating some of the possible mechanisms behind host control of Gyrodactylus infection in salmonids. Polyclonal and monoclonal antibodies against the T-cell marker CD3, B-lymphocytes, neutrophilic granulocytes and collectin showed reactivity with cells in the epidermal layer of infected and non-infected rainbow trout. Only the antibody against IgM showed no reactivity with antigen epitopes in skin and fins. This lack of reactivity indicates that $\mathrm{IgM}$ is not present or merely present in very low concentrations. Results from a previous study indicated the presence of IgM in mucus from skin of Atlantic salmon (Hatten et al. 2001). However, our results from the immunohistochemical investigation support real-time PCR results indicating that IgM plays no significant role in rainbow trout control of infection with the Danish strain of G. salaris. The polyclonal antibody, generated against the human T-cell marker CD3, reacted weakly with cells situated between the epidermal cells as observed in a previous study on putative T-cells in the epidermis of Atlantic salmon (Bakke-McKellep et al. 2007). However, no differences were seen between infected and non-infected tissue. This supports results from our gene expression analysis, showing that genes encoding markers for T-cell mediated adaptive immune activity (CD-4, CD-8 and TCR- $\alpha$ ) were all un-regulated. Thus, our results do not support that presentation of Gyrodactylus epitopes and a subsequent T-cells response is important in control of this particular strain of G. salaris. Immunohistochemical staining with antibody against collectin showed reactivity with mucous cells in the epidermal layer of both skin and fins. This suggests the presence of collectins in rainbow trout mucus but this needs further confirmation. Fish mucus is composed of mucopolysaccharides and it is important to consider the possibility that the antibody will cross-react with polysaccharide epitopes found in fish mucus. Therefore, further epitope analysis should be conducted on the collectin in this context. No differences in antibody reactivity between infected and non-infected tissue was seen. Therefore, it is still uncertain if collectin plays a role in the control of gyrodactylid infections of trout. Antibody against neutrophilic granulocytes reacted with mucous cells in the epidermis of skin and fin tissue. In skin, staining of a few cells scattered between the epidermal cells was seen. Neutrophilic granulocytes are known to be associated with mucosal surfaces in humans and play a key role in production of mucus in asthma. A study on guinea pigs suggested goblet/mucous cell degranulation to be dependent on the presence of neutrophils (Takeyama et al. 1998). Whether the staining of mucous cells is due to neutrophils associated with mucous cells needs further elucidation. It cannot be excluded that the antibody reacts with a carbohydrate epitope which would lead to crossreaction with mucopolysaccharides in trout mucous cells. No differences in reactivity of the antibody were observed between infected and non-infected tissue. A weak reaction of monoclonal antibody against B-lymphocytes was seen in cells scattered in the epidermis of both skin and fin tissue. Staining was also observed in deeper layers within and beneath the epidermis of both skin and fin tissue. The possibility of B-cells being present in the epidermis of rainbow trout is worth noting. Epithelial-associated B-cells are known from mammals and at present it is debated if this is a separate subset of B-cells (Jöhrens et al. 2005). It cannot be ruled out that a corresponding subset of B-cells is present in salmonids. But we saw no difference in antibody reactivity between infected and non-infected fish. Using the same antibody against B-lymphocytes (G2H3) in flow cytometry, a previous study described no increased number of B-cells in blood and head kidney of salmon infected with infectious pancreatic necrosis virus (IPNV) compared to non-infected control fish (Rønneseth et al. 2006). Our results indicate that B-cell mediated immunity is of little importance in control of the Danish strain of G. salaris, at least at the infection levels observed in the present study. This corresponds to previous work (Harris et al. 1998, Buchmann 1998, Buchmann et al. 2004) demonstrating lack of antibody involvement in trout responding to gyrodactylids.

Acknowledgements. The present work was conducted under the Danish Fish Immunology Research Network DAFINET (www.dafinet.dk) supported by grant 2101-08-0017 from the Danish Research Council for Strategic Research. The authors are indebted to Professor Heidrun Wergeland, The University of Bergen, Norway, for providing antibodies against leucocyte markers.

\section{REFERENCES}

Appleby C., Mo T.A. 1997: Population dynamics of Gyrodactylus salaris (Monogenea) infecting Atlantic salmon, Salmo salar, parr in the river Batnfjordselva, Norway. J. Parasitol. 83: 23-30.

Bakke T.A., Harris P.D., Cable J. 2002: Host specificity dynamics: observations on gyrodactylid monogeneans. Int. J. Parasitol. 32: $281-308$.
Bakke T.A., Mackenzie K. 1993: Comparative susceptibility of native Scottish and Norwegian stocks of Atlantic salmon, Salmo salar L., to Gyrodactylus salaris Malmberg: laboratory experiments. Fish. Res. 17: 69-85.

Bakke-McKellep A.M., Frøystad M.K., Lilleeng E., Dapra F., Refstie S., Krogdahl Å., Landsverk T. 2007: Response 
to soy: T-cell like reactivity in the intestine of Atlantic salmon, Salmo salar L. J. Fish Dis. 30: 13-25.

Buchmann K. 1998: Binding and lethal effect of complement from Oncorhynchus mykiss on Gyrodactylus derjavini (Platyhelminthes: Monogenea). Dis. Aquat. Org. 32: 195-200.

Buchmann K., Bresciani J. 1999: Rainbow trout leucocyte activity: influence on the ectoparasitic monogenean Gyrodactylus derjavini. Dis. Aquat. Org. 35: 13-22.

BuchmanN K., Lindenstrøm T. 2002: Interactions between monogenean parasites and their fish hosts. Int. J. Parasitol. 32: 309319 .

Buchmann K., Madsen K.K., Dalgaard M.B. 2004: Homing of Gyrodactylus salaris and G. derjavini (Monogenea) on different hosts and response post-attachment. Folia Parasitol. 51: 263-267.

Buchmann K., Uldal A. 1997: Gyrodactylus derjavini infections in four salmonids: comparative host susceptibility and site selection of parasites. Dis. Aquat. Org. 28: 201-209.

Bush A.O., Lafferty K.D., Lotz J.M., Shostak A.W. 1997: Parasitology meets ecology on its own terms: Margolis et al. revisited. J. Parasitol. 83: 575-583.

Collins C.M., Olstad K., Sterud E., Jones C.S., Noble L.R., Mo T.A., Cunningham C.O. 2007: Isolation of a FIP2-like gene from Atlantic salmon (Salmo salar L.) found upregulated following infection with the monogenean parasite Gyrodactylus salaris Malmberg, 1957. Fish Shellfish Immunol. 22: 282-288.

Dalgaard M.B., Larsen T.B., Jorndrup S., Buchmann K. 2004: Differing resistance of Atlantic salmon strains and rainbow trout to Gyrodactylus salaris infection. J. Aquat. Anim. Health 16: 109-115.

Dalgaard M.B., Nielsen C.V., Buchmann K. 2003: Comparative susceptibility of two races of Salmo salar (Baltic Lule river and Atlantic Conon river strains) to infection with Gyrodactylus salaris. Dis. Aquat. Org. 53: 173-176.

Harris P.D., Soleng A., Bakke T.A. 1998: Killing of Gyrodactylus salaris (Platyhelminthes, Monogenea) mediated by host complement. Parasitology 117: 137-143.

Hatten F., Frederiksen A., Hordvik I., Endersen C. 2001: Presence of IgM in cutaneous mucus, but not in gut mucus of Atlantic salmon, Salmo salar. Serum IgM is rapidly degraded when added to gut mucus. Fish Shellfish Immunol. 11: 257-268.

Heggberget T.G., Johnsen B.O., Hindar K., Jonsson B., Hansen L.P., Hvidsten N.A., Jensen A.J. 1993: Interactions between wild and cultured Atlantic salmon - a review of the Norwegian experience. Fish. Res. 18: 123-146.

Heinecke R.D., Martinussen T., Buchmann K. 2007: Microhabitat selection of Gyrodactylus salaris Malmberg, 1957 on different salmonids. J. Fish Dis. 30: 733-743.

Jensen A.J., Johnsen B.O. 1992: Site specificity of Gyrodactylus salaris Malmberg, 1957 (Monogenea) on Atlantic salmon (Salmo salar L.) in the River Lakselva, northern Norway. Can. J. Zool. 70: 264-267.

JoHNSEN B.O. 1978: The effect of an attack by the parasite Gyrodactylus salaris on the population of salmon parr in the River Lakselva, Misvaer in northern Norway. Astarte 11: 7-9.

Johnsen B.O., Jensen A.J. 1986: Infestations of Atlantic salmon, Salmo salar, by Gyrodactylus salaris in Norwegian rivers. J. Fish Biol. 29: 233-241.

Jöhrens K., Shimizu Y., Anagnostopoulos L., Schiffmann S., Tiacci E., Falini B., Stein H. 2005: T-bet-positive and IRTA1- positive monocytoid B cells differ from marginal zone B cells and epithelial-associated B cells in their antigen profile and topographical distribution. Haematologica 90: 1070-1077.

Jørgensen L.G., Heinecke R.D., Kania P., Buchmann K. 2008: Occurrence of gyrodactylids on wild Atlantic salmon, Salmo salar L., in Danish rivers. J. Fish Dis. 31: 127-134.

Jørgensen T.R., Larsen T.B., Jørgensen L.G., Bresciani J., KaNIA P.W., Buchmann K. 2007: Characterisation of a low pathogenic form of Gyrodactylus salaris from rainbow trout. Dis. Aquat. Org. 73: 235-244.

Kania P., Jørgensen T.R., Buchmann K. 2007: Differentiation between a pathogenic and a non-pathogenic form of Gyrodactylus salaris using PCR-RFLP. J. Fish. Dis. 30: 123-126.

Kania P., Koch C., Vitved L., Skjødt K. 2005: The collectin system in carp and rainbow trout. In: K. Buchmann (Ed). Diagnosis and Control of Fish Diseases, Immunology Aspects. A two day workshop, November 2 and 3, Frederiksberg, Denmark. Book of Abstracts. (www.fishnet.dk).

Lindenstrøm T., Buchmann K., Secombes C.J. 2003: Gyrodactylus derjavini infection elicits IL-1 $\beta$ expression in rainbow trout skin. Fish Shellfish Immunol. 15: 107-115.

Lindenstrøm T., Collins C., Bresciani M.J., Cunningham C.O. BuchmanN K. 2003: Characterization of a Gyrodactylus salaris variant: infection biology, morphology and molecular genetics. Parasitology 127: 165-177.

Lindenstrøm T., Secombes C.J., Buchmann K. 2004: Expression of immune response genes in rainbow trout skin induced by $G y$ rodactylus derjavini infections. Vet. Immunol. Immunopathol. 97: 137-148.

Lindenstrøm T., Sigh J., Dalgaard M.B., Buchmann K. 2006: Skin expression of IL-1 $\beta$ in East Atlantic salmon, Salmo salar L., highly susceptible to Gyrodactylus salaris infection is enhanced compared to a low susceptibility Baltic stock. J. Fish Dis. 29: 123-128.

Livak K.J., Schmittgen T.D. 2001: Analysis of relative gene expression data using real-time quantitative PCR and the $2-\Delta \Delta \mathrm{CT}$ method. Methods 25: 402-408.

Matejusová I., Felix B., Sorsa-Leslie T., Gilbey J., Noble L.R., Jones C.S., Cunningham C.O. 2006: Gene expression profiles of some immune relevant genes from skin of susceptible and responding Atlantic salmon (Salmo salar L.) infected with Gyrodactylus salaris (Monogenea) revealed by suppressive subtractive hybridisation. Int. J. Parasitol. 36: 1175-1183.

Pettersen E.F., Fyllingen I., Kavlie A., Maaseide N.P., Glette J., Endresen C., Wergeland H.I. 2005: Monoclonal antibodies reactive with serum IgM and leukocytes from Atlantic salmon (Salmo salar L.). Fish Shellfish Immunol: 5: 275-287.

Raida M.K., Buchmann K. 2008: Development of adaptive immunity in rainbow trout, Oncorhynchus mykiss (Walbaum) surviving an infection with Yersinia ruckeri. Fish Shellfish Immunol. 25: 533-541.

Rønneseth A., Pettersen E.F., Wergeland H.I. 2006: Neutrophils and B-cells in blood and head kidney of Atlantic salmon (Salmo salar L.) challenged with infectious pancreatic necrosis virus (IPNV). Fish Shellfish Immunol. 20: 610-620.

Takeyama K., Agustí C., Ueki I., Lausier J., Cardell L.O., NADEL J.A. 1998: Neutrophil-dependent goblet cell degranulation: role of membrane-bound elastase and adhesion molecules. AJP - Lung Cell. Mol. Physiol. 275: 294-302. 